\title{
Kedudukan dan Standarisasi Kafaah dalam Pernikahan Perspektif Ulama Madzhab Empat
}

\author{
Ahmad Muzakki \\ Universitas Islam Zainul Hasan Genggong Probolinggo \\ muzakkipasca@gmail.com \\ Himami Hafshawati \\ Universitas Islam Zainul Hasan Genggong Probolinggo \\ himamihafsha@gmail.com
}

\begin{abstract}
Marriage is a human need that must be met, because it is a biological and psychological need that cannot be separated from human life. Marriage is a sequence of sexual desires that humans have. However, apart from these various reasons, Islam considers the existence of compatibility and compatibility between the two people who will lead family life. In the language of fiqh, this compatibility is called kafaah. For reasons not working, many couples fail to navigate the household ark. Everyone has different perceptions about the criteria for kafaah. So it is important to describe in this article the views of the four schools of thought about standardization of kafaah and its position in marriage. $n$ this article, it can be concluded that kafaah has an important role in marriage and the standards vary among madzab scholars, four of which are lineage, wealth, religious quality, work and independence.
\end{abstract}

Key Word : Kafaah, standardization, Madzhab Empat

\begin{abstract}
Abstrak
Pernikahan merupakan sebuah kebutuhan manusia yang harus dipenuhi, karena hal itu merupakan kebutuhan biologis dan psikologis yang tidak bisa dipisahkan dari kehidupan manusia. Pernikahan merupakan runtutan dari hasrat seksualitas yang dimiliki manusia. Namun, terlepas dari berbagai alasan tersebut, Islam mempertimbangkan adanya kecocokan dan kesesuaian antara kedua insan yang akan menjalani kehidupan keluarga. Dalam bahasa fiqhnya kecocokan itu disebut dengan kafaah. Karena alasan tidak kafaah banyak pasangan gagal mengarungi bahtera rumah tangga. Setiap orang mempunyai persepsi berbeda-beda tengan kriteria-kriteria kafaah. Maka penting untuk dipaparkan dalam artikel ini terkait pandangan-pandangan ulama madzhab empat tentang standarisasi kafaah dan kedudukannya dalam pernikahan. Dalam artikel ini didapat kesimpulan bahwa kafaah memiliki peranan penting dalam pernikahan dan standarisasinya berbeda-beda diantara ulama madzab empat diantaranya adalah nasab, kekayaan, kualitas keagamaan, pekerjaan dan kemerdekaan.
\end{abstract}

Kata Kunci : Kafaah, Standarisasi, Madzhab Empat 


\section{A. PENDAHULUAN}

Tujuan pernikahan adalah mewujudkan rumah tangga yang sakinah. Banyak cara yang dapat dilakukan untuk mencapai tujuan tersebut. Salah satunya adalah upaya mencari calon istri atau suami yang baik. Upaya mendapatkan pasangan hidup yang tepat dalam pernikahan akan menentukan baik tidaknya kehidupan rumah tangga.

Penentuan kriteria calon istri dan suami dalam fiqh pernikahan diatur secara khusus dalam bab kafaah. Kafaah merupakan keseimbangan atau kesepadanan antara calon suami dan isteri dalam hal-hal tertentu, seperti agama, nasab, pekerjaan, merdeka dan harta. Keberadaan kafaah sangatlah penting dalam pernikahan untuk menunjang kehidupan rumah tangga yang harmonis.

Ulama madzhab empat berbeda pendapat baik berkenaan dengan standarisasi kafaah maupun kedudukannya dalam pernikahan. Perbedaan dari masing-masing madzhab didasarkan atas dalil-dalil, baik naqli maupun aqli. Ada sebagian ulama yang berpendapat hanya agamalah yang menjadi standarisasi kafaah. Sedangkan sebagian yang lain tidak hanya mencukupkan dengan agama. Berkaitan dengan kedudukan kafaah ulama juga berbeda pendapat. Ada yang mengatakan tidak penting, ada yang berpendapat penting, bahkan ada yang menganggap kafaah sebagai syarat lazim dalam sebuah pernikahan.

Para pengkaji hukum Islam perlu memahami permasalahan ini secara tuntas. Kadang kafaah menjadi penghalang berlangsungnya sebuah pernikahan. Disisi lain, tanpa kafaah perjalanan pernikahan kadang tidak berjalan dengan baik. Pemahaman yang komprehensif tentang kafaah dapat mengantarkan kepada kemaslahatan pernikahan dan menciptakan sikap moderat dalam memposisikan kafaah, khususnya berkaitan dengan masalah kedudukan dan standarisasinya dalam pernikahan.

Jenis penelitian yang digunakan dalam penulisan artikel jurnal ini adalah penelitian literature atau penelitian kepustakaan (library Research), yaitu penelitian yang menggunakan literatur kepustakaan. Menurut Noeng Muhajir penelitian literatur lebih menekankan olahan filosofis dan teoritis dari pada uji empiris di lapangan sebagai suatu penelitian literatur yang akan menganalisis secara komparatif ${ }^{1}$.

Maka secara metodologis penelitian ini menggunakan pendekatan filosofis (Philosopical Aproach), yang akan digunakan untuk mengkaji pemikiran Ulama

\footnotetext{
${ }^{1}$ Noeng Muhajir, Metodologi Penelitian Filsafat, (Yogyakarta: Rike Sarasin, 1996), 59.
} 
madzhab empat. Data primer dari penelitian ini adalah kitab fiqh madzhab empat diantaranya Fiqh 'Ala Al-Madzahib Al-Arba'ah karya Abdur Rahman Al-Jaziri, alFiqh al-Islami Wa Adillatuhu karya Wahbah Azzuhaily dan Fiqh Sunnah karya Sayyid Sabiq.

\section{B. PEMBAHASAN}

\section{Pengertian Kafaah dalam Pernikahan}

Perlu dijelaskan terlebih dahulu pengertian kafaah di dalam pernikahan. Kafaah berasal dari bahasa arab, dari kata كفئ yang artinya adalah sama atau setara. Kata ini merupakan kata yang terpakai dalam bahasa arab dan terdapat dalam Alquran dengan arti "sama" atau setara. Dalam Alquran terdapat contoh kata ini di surat al-Ikhlas ayat 4 yaitu " yang berarti tidak satupun yang sama denganNya.

Kafaah secara etimologi adalah sama, sesuai dan sebanding. ${ }^{2}$ Sehingga yang dimaksud kafaah dalam perkawinan adalah kesamaan antara calon suami dan calon istri, sama dalam kedudukan, sebanding dalam tingkat sosial dan sama dalam akhlak dan kekayaan. ${ }^{3}$ Namun para ulama Imam Madzhab berbeda pendapat dalam memberi pengertian kafaah dalam perkawinan. Perbedaan ini terkait dengan perbedaan ukuran kafaah yang mereka gunakan. Menurut ulama Hanafiyah, kafaah adalah persamaan laki-laki dengan perempuan dalam nasab, Islam, pekerjaan, merdeka, nilai ketakwaan dan harta. ${ }^{4}$ Dan menurut ulama Malikiyah, kafaah adalah persamaan laki-laki dengan perempuan dalam agama dan selamat dari cacat yang memperoleh seorang perempuan untuk melakukan khiyar terhadap suami. ${ }^{5}$

Sedangkan menurut ulama Syafi'iyyah, kafaah adalah persamaan suami dengan isteri dalam kesempurnaan atau kekurangannya baik dalam hal agama, nasab, merdeka, pekerjaan dan selamat dari cacat yang memperbolehkan seorang perempuan untuk melakukan khiyar terhadap suami. Dan menurut ulama Hanabilah, kafaah adalah persamaan suami dengan isteri dalam nilai ketakwaan,

\footnotetext{
${ }^{2}$ Qosim Bin Abdullah Bin Amir `Ali al-Qunuwi, Anisul Fuqoha`Fi Ta`rifil alfadz al-Mutadawilah Bainal Fuqoha', (Beirut: Darul Fikr, 1999) Juz 1, 149.

${ }^{3}$ Sayyid Sabiq, Fiqh As-Sunnah, (Mesir : Darul Hadist, 2004), 572.

${ }^{4}$ Abdur Rahman Al-Jaziri, Fiqh 'Ala Al-Madzahib Al-Arba'ah, (Beirut: Darul Kutub Ilmiyah) Juz 4, 533.

${ }^{5}$ Wahbah Zuhaily, al-Fiqh al-Islami Wa Adillatuhu , (Damaskus : Darul Fikr, 1985 ), Juz 7, 240.
} 
pekerjaan, harta, merdeka, dan nasab. ${ }^{6}$ Meskipun masalah keseimbangan itu tidak diatur dalam Undang-Undang Perkawinan atau dalam Alquran, akan tetapi masalah tersebut sangat penting untuk mewujudkan suatu rumah tangga yang harmonis dan tentram, sesuai dengan tujuan perkawinan itu sendiri, yaitu ingin mewujudkan suatu keluarga yang bahagia berdasarkan cinta dan kasih sayang sehingga masalah keseimbangan dalam perkawinan ini perlu diperhatikan demi mewujudkan tujuan perkawinan. Dari definisi yang telah diterangkan, dapat diambil kesimpulan bahwa kafaah merupakan keseimbangan atau kesepadanan antara calon suami dan isteri dalam hal-hal tertentu, yaitu agama, nasab, pekerjaan, merdeka dan harta.

Sedangkan Nabi Muhammad SAW. memberikan ajaran mengenai ukuranukuran kufu' dalam perkawinan agar mendapatkan kebahagiaan dalam rumah tangga berdasarkan Hadits Nabi SAW.

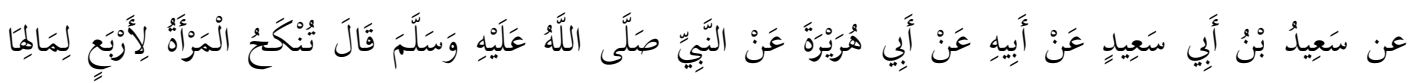

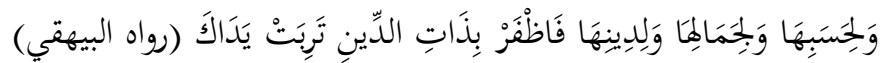

"Dari Said bin Abi Said dari ayahnya dari Abu Hurairah dari Nabi SAW. : Sesungguhnya beliau bersabda: " perempuan dinikahi karena empat perkara: pertama karena hartanya, kedua karena derajatnya, (nasabnya), ketiga kecantikannya, keempat agamanya, maka pilihlah karena agamanya, maka terpenuhi semua kebutuhanmu”.'(HR. Baihaqi) ${ }^{7}$

Dalam Hadits di atas dijelaskan bahwa jika seorang laki-laki akan menikahi seorang perempuan, biasanya ada empat perkara yang diperhatikan yaitu hartanya, derajatnya (nasabnya), kecantikannya, dan agamanya. Namun Nabi SAW. sangat menekankan faktor agama untuk dijadikan pertimbangan dalam memilih pasangan.

Segolongan ulama ada yang memahami faktor agamalah yang dijadikan pertimbangan karena didasarkan pada penekanan sabdanya :

$$
\text { فَاظْفْرُ بِذَاتِ الدَّينِ تَربَتْنْ يَدَاكَ }
$$

Segolongan lainnya berpendapat bahwa faktor keturunan (nasab) dalam pernikahan sama kedudukannya dengan faktor agama, demikian pula faktor kekayaan. ${ }^{8}$

\footnotetext{
${ }^{6}$ Sayyid Sabiq, Fiqh As-Sunnah, (Mesir : Darul Hadist, 2004), 577.

${ }^{7}$ Imam al-Baihaqi, Sunan Sughro Lil Baihaqi, Damaskus : Darut Tauqi an-Najah, 2002), Juz 2, 202.

${ }^{8}$ Ibnu Rusyd, Bidayatul Mujtahid, (Beirut : Darul Ibni `Asshoshoh, 2005), Juz 2, 14.
} 
Sedangkan pernikahan itu sendiri adalah terjemah dari kata nakaha dan zawaja, az-zauj merupakan salah satu bentuk khas percampuran antara golongan dan diartikan sebagai pasangan dengan lainnya. Az-zaujah artinya wanita pasangan laki-laki dan az-zauj artinya pasangan wanita atau biasa disebut dengan suami.

Pernikahan yang berasal dari kata dasar nikah mempunyai 3 macam arti. Pertama, arti menurut bahasa adalah berkumpul. Kedua, arti menurut ahli Ushul, arti menurut para Ahli Ushul terbagi menjadi 3, menurut golongan Hanafiyah nikah menurut arti aslinya adalah setubuh dan menurut arti majazi adalah akad yang menjadikan halal hubungan kelamin antara laki-laki dan perempuan.

Golongan Syafi'iyah berpendapat bahwa nikah menurut arti aslinya adalah akad yang menjadikan halal hubungan kelamin antara laki-laki dan perempuan, arti majazinya adalah setubuh. Sedangkan menurut Abu Al-Qasim az-Zajjad, Imam Yahya, Ibnu Hazm dan sebagian ahli ushul dari sahabat Abu Hanifah adalah gabungan antara akad dan setubuh. Ketiga, nikah menurut Ulama Fiqh, nikah adalah akad yang diatur oleh agama untuk memberikan kepada laki-laki hak memiliki penggunaan faraj wanita dan seluruh tubuhnya untuk penikmatan sebagai tujuan primer. ${ }^{9}$

\section{Dasar Hukum Kafaah}

Pertimbangan kafaah dalam pernikahan disandarkan pada Hadits yang diriwayatkan oleh nabi berikut ini:

a. Riwayat dari Ali Ibn Abi Thalib RA, bahwasanya Rasulullah saw bersabda kepadanya,

$$
\text { يا علي ثلاثة لاتؤخر الصلاة اذا اتت والجنازة اذا حضرة والايم اذا وجدت كفؤا (رواه البيهقي) }
$$

"Hai Ali, janganlah engkau mengakhirkan (menunda-nunda) tiga hal :sholat jika telah tiba waktunya, jenazah jika telah hadir (untuk segera diurus dan dikuburkan), dan anak perempuan yang siap menikah jika telah engkau dapatkan yang sekufu dengannya". (HR. Baihaqi) ${ }^{10}$

b. Riwayat dari Aisyah ra, bahwasanya Rasulullah saw bersabda,

${ }^{9}$ Ibrahim Hosen, Fiqh Perbandingan Dalam Masalah Pernikahan , (Jakarta: Pustaka Firdaus , 2003), 116.

10 Muhammad Bin Abdillah Abu Abdillah al-Hakim an-Naisaburi, Al-Mustadrok `Ala asShohihaini, (Beirut : Darul Kutub Ilmiyah, 1990), Juz 2, 176. 


$$
\text { تخيروا لنطفكم فأنكحوا الا اكفاء وانكحوا اليهم (رواه ابن ماجه) }
$$

"Pilih-pilihlah untuk tempat tumpahnya nuthfah kalian (maksudnya isteri), dan nikahkanlah orang-orang yang sekufu”. (HR. Ibnu Majah) ${ }^{11}$

c. Atsar dari Umar Ibn Al-Khaththab RA. Beliau berkata, "Sungguh aku melarang dihalalkannya kemaluan para wanita yang terhormat nasabnya, kecuali dengan orang-orang yang sekufu". ${ }^{12}$

d. Hadist yang diriwayatkan dari Jabir bin Abdillah An-Anshori, bersabda Rasulullah SAW:

$$
\text { ألا لايزوج النساء إلا الأولياء ولا يزوجن من غير الأكفاء }
$$

"Janganlah engkau menikahi wanita kecuali dengan izin walinya, dan janganlah engkau menikahinya kecuali dengan yang sekufu."

e. Hadits yang diriwayatkan dari `Aisyah, Rasulullah saw bersabda:

$$
\text { تخيروا لنطفكم ولا تضعوها في غير الأكفاء (رواه الدارقطني) }
$$

"Pilihlah wanita sebagai wadah untuk menumpahkan nutfahmu, janganlah letakkan nutfahmu ke (rahim) wanita yang tidak sekufu. " (HR. Daruqutni) ${ }^{13}$

\section{Tujuan Kafaah dalam Pernikahan}

Tujuan keseimbangan (kafaah) dalam perkawinan sama dengan tujuan perkawinan, yaitu untuk membentuk keluarga yang bahagia dan kekal berdasarkan Tuhan Yang Maha Esa. Kebahagiaan dalam rumah tangga, tentulah menjadi tujuan yang ingin diperoleh mereka yang mendirikannya. Sangatlah tepat jika pada setiap orang yang berniat mendirikan rumah tangga dan berkeinginan mencapai kebahagiaan hidup di dalamnya, memilih niat yang baik dan senantiasa berupaya semaksimal mungkin untuk mendapatkannya. Untuk itu, diperlukan adanya keseimbangan sebab tujuan keseimbangan dalam perkawinan tidak lepas dari tujuan perkawinan itu sendiri. ${ }^{14}$

Untuk mewujudkan suatu rumah tangga yang harmonis dan tentram diperlukan adanya kafaah (keseimbangan dalam perkawinan), karena masalah

\footnotetext{
${ }^{11}$ Jalaluddin as-Suyuthi, Jami`u al-Ahadist, , (Beirut : Darul Ibni `Asshoshoh, 2005), Juz 11, hal. 234.

${ }^{12}$ Syaikh Imad Zaki al-Barudi, Tafsir Wanita, Jakarta: Pustaka al-Kautsar, 2008), 67.

${ }^{13}$ Imam Suyuthi, Jami`ul Kabir, (Beirut : Darul Kutub Ilmiyah, 1990), Juz 1, 843.
} 
kafaah ini sangat penting dalam masalah rumah tangga. Agar antara calon suamiistri tersebut ada keseimbangan dalam membina keluarga yang tentram dan bahagia. Jika di antara keduanya sudah ada keseimbangan dan kecocokan, maka akan mudah bagi mereka untuk mewujudkan tujuan perkawinan.

Dengan demikian, jelaslah keseimbangan (kafaah) dalam perkawinan sangat diperlukan untuk mewujudkan keluarga yang tentram dan bahagia. Dan akibat dari tidak adanya keseimbangan dalam perkawinan, keluarga tersebut akan mengalami kegoncangan dalam rumah tangga, karena tidak ada kecocokan (keseimbangan) di antara keduanya. ${ }^{15}$

\section{Orang yang Berhak Menentukan Kafaah}

Para fuqaha' sepakat bahwa yang berhak menentukan kafaah adalah seorang perempuan dan walinya, karena menurut mereka seorang perempuan dan walinya biasanya akan merasa terhina bila menikah dengan laki-laki yang tidak sekufu'. Sedangkan laki-laki yang terpandang tidak akan merasa terhina bila menikah dengan perempuan yang status sosialnya lebih rendah darinya.

Dalam menentukan kafa'ah, antara wali dengan anak perempuan yang akan menikah mempunyai hak yang sama. Apabila seorang wali mengawinkan anaknya anak perempuan tersebut menganggap calon suaminya tidak sekufu' dengannya. Maka ia boleh mengajukan fasah nikah. Begitu juga sebaliknya, jika seorang anak perempuan menikah dengan laki-laki yang tidak sekufu' dan walinya tidak merestui, maka wali boleh mengajukan fasah nikah.

Golongan Malikiyah berpendapat bahwa wali dapat merusak perkawinan anak perempuannya selama belum di dukhul oleh suaminya. Jika antara keduanya telah melakukan hubungan badan. Maka pernikahan tersebut tidak dapat fasah. Sedangkan menurut ulama Hanafiyah dan Syafi'iyah, pernikahan itu dapat difasah sebelum anak perempuan itu hamil atau melahirkan. ${ }^{16}$

\section{Waktu Berlakunya Kafaah}

Waktu yang ditetapkan untuk menentukan apakah calon-calon mempelai telah sekufu' atau belum, itu letaknya pada waktu akan dilaksanakan akad nikah.

${ }^{15}$ Imam Syafi'i. "Konsep Kafaah Dan Keluarga Sakinah (Studi Analisis Tentang Korelasi Hak Kafa'ah Terhadap Pembentukan Keluarga Sakinah)". Asy-Syari'ah: Jurnal Hukum Islam 6, no. 1 (15 Februari 2020): 33.

\footnotetext{
${ }^{16}$ Sayyid Sabiq, Fiqh As-Sunnah, (Mesir : Darul Hadist, 2004), 577.
} 
Menurut H. S. A. Al-Hamdani tentang berlakunya kafaah yaitu dinilai pada waktu terjadinya akad. Apabila keduanya berubah sesudah terjadinya akad maka tidak mempengaruhi akad karena syarat akan diteliti pada waktu akad. Oleh sebab itu apabila seseorang pada waktu akad mempunyai pencaharian yang terhormat, mampu memberi nafkah atau orangnya sholeh, kemudian berubah menjadi hina, tidak sanggup memberi nafkah atau fasiq terhadap perintah Allah SWT dan semuanya itu terjadi setelah dilangsungkan perkawinan, maka akadnya tetap berlaku. $^{17}$

Untuk menghindari terjadinya hal-hal yang tidak diinginkan sesudah dilangsungkan pernikahan, maka hendaknya pihak yang mempunyai hak dalam menentukan kafaah menyatakan pendapatnya tentang kedua mempelai pada saat akad nikah. Dan sebaliknya persetujuan tentang kafaah ini dicatat oleh pihak-pihak yang berhak sehingga dapat dijadikan sebagai alat bukti seandainya ada pihak yang akan menggugat di kemudian hari. ${ }^{18}$

Hal semacam ini mengandung hikmah supaya perkawinan yang dilangsungkan itu betul-betul diteliti terlebih dahulu dan seorang yang akan mau menikah harus mempunyai niat yang sungguh-sungguh agar tidak ada penyesalan dalam pernikahan.

Dalam Fiqh Sunnah dijelaskan bahwa kufu' diukur ketika berlangsungnya akad nikah. Jika selesai akad nikah terjadi kekurangan-kekurangan, hal itu tidaklah mengganggu dan tidak dapat membatalkan sedikitpun apa yang sudah terjadi, serta tidak mempengaruhi hukum akad nikahnya. Jika pada waktu berlakunya akad nikah, suami memiliki pekerjaan terhormat dan mampu memberi nafkah istrinya atau dia seorang yang salah, tetapi di kemudian hari ada perubahan, misalnya pekerjaannya kasar, atau tidak mampu lagi memberi nafkah, atau setelah kawin berbuat durhaka kepada Allah, maka akad nikahnya tetap sah seperti sebelumnya. ${ }^{19}$

Memang masa itu berbolak-balik dan manusia tidak selamanya langgeng keadaannya dalam satu sifat saja. Karena itulah istri harus dapat menerima

17 Muzakki, Ahmad. 2017. "Kafaah Dalam Pernikahan Endogami Pada Komunitas Arab Di Kraksaan Probolinggo". Istidlal: Jurnal Ekonomi Dan Hukum Islam 1 (1), 19.

${ }^{18}$ Imam Syafi'i. 2020. "Konsep Kafaah Dan Keluarga Sakinah (Studi Analisis Tentang Korelasi Hak Kafa'ah Terhadap Pembentukan Keluarga Sakinah)". Asy-Syari'ah: Jurnal Hukum Islam 6 (1), 40.

${ }^{19}$ Abu Yazid Adnan Quthny (2016) "Reformasi Hukum Keluarga Islam Turki (Status Poligami dalam Perspektif Teori Linguistik-Semantik Muhammad Shahrur)”, Asy-Syari'ah: Jurnal Hukum Islam , 2 (1), 15. 
kenyataannya, bersabar dan bertaqwa kepada Allah. Karena sabar dan bertakwa kepada Allah merupakan watak orang-orang yang besar. ${ }^{20}$

\section{Kedudukan Kafaah dalam Pernikahan Menurut Ulama Madzhab Empat}

Dalam Alquran tidak disebutkan secara jelas tentang konsep kafaah dalam perkawinan. Oleh karena itu para ulama berbeda pendapat dalam masalah ini, apakah kafaah penting dalam sebuah perkawinan atau tidak. Ibnu Hazm berpendapat bahwa kafaah tidak penting dalam sebuah perkawinan, menurutnya antara orang Islam yang satu dengan orang Islam yang lainnya adalah sama (sekufu'). Semua orang Islam asalkan dia tidak pernah berzina, maka ia berhak kawin dengan semua wanita muslimah yang tidak pernah berzina. ${ }^{21}$

Berdasarkan firman Allah SWT QS. Al-Hujurat :

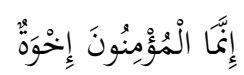

"Sesungguhnya orang-orang mu'min adalah bersaudara ....". (QS. Al-Hujurat $: 10)^{22}$

Begitu juga dengan al-Hasan al-Basri, as-Sauri, dan al-Karkhi berpendapat bahwa kafaah bukanlah faktor penting dalam perkawinan dan tidak termasuk syarat sah atau syarat lazim perkawinan. Menurut mereka, ketidakkufu'an calon suami dan calon isteri tidak menjadikan penghalang kelangsungan perkawinan tersebut. ${ }^{23}$ Alasan-alasan mereka berdasarkan firman Allah SWT. :

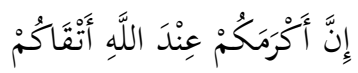

"Sesungguhnya orang yang paling mulia di antara kamu di sisi Allah ialah orang yang paling bertakwa di antara kamu. ". (QS. Al-Hujurat : 13). ${ }^{24}$

Dari ayat-ayat di atas dapat disimpulkan bahwa semua manusia sama dalam hak dan kewajiban, tidak ada keistimewaan antara yang satu dengan lainnya

\footnotetext{
${ }^{20}$ Sayyid Sabiq, Fiqh As-Sunnah, (Mesir : Darul Hadist, 2004), 577.

${ }^{21}$ Sayyid Sabiq, Fiqh As-Sunnah, (Mesir : Darul Hadist, 2004), 572.

516.

${ }_{22}$ Departemen Agama RI, Al-Qur'an dan Terjemahnya, (Bandung : Jabal Raudlotul Jannnah, 2010),

${ }^{23}$ Wahbah Zuhaily, al-Fiqh al-Islami Wa Adillatuhu , (Damaskus : Darul Fikr, 1985 ) Juz 7, 230.

${ }^{24}$ Departemen Agama RI, Al-Qur'an dan Terjemahnya, (Bandung : Jabal Raudlotul Jannnah, 2010), 517.
} 
kecuali dengan takwa. Dan mereka juga menyatakan bahwa penghormatan dan penghargaan terhadap darah seseorang dalam hukum pidana ialah sama saja. Jika yang membunuh adalah orang yang terhormat dan yang dibunuh adalah orang jelata, maka hukuman qishash tetap dijalankan. Jika kekufu'an diterapkan dalam hukum pidana Islam, maka begitu pula ketentuan dalam perkawinan seharusnya tidak diterapkan. ${ }^{25}$

Dalil sahnya suatu pernikahan yang tidak sekufu adalah Hadits yang mengisahkan tentang pernikahan antara Fatimah binti Qois dan Usamah, padahal Fatimah binti Qois adalah wanita merdeka dan keturunan dari suku Quraisy sedangkan Usamah adalah seorang budak. Dalam kitab Sunan Shugro Lil Baihaqi ditulis Hadits sebagai berikut,

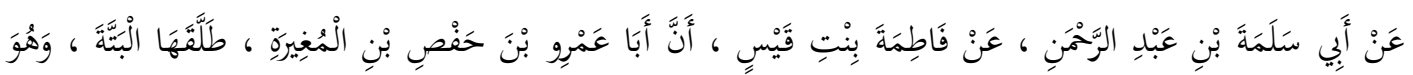

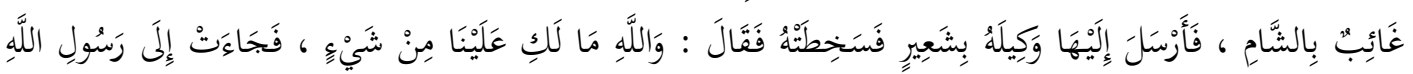

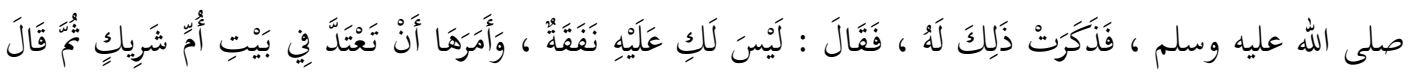

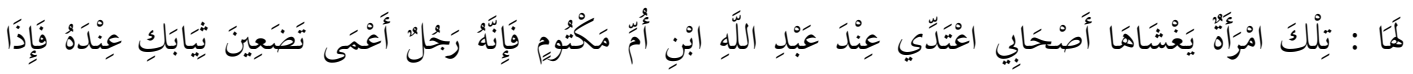

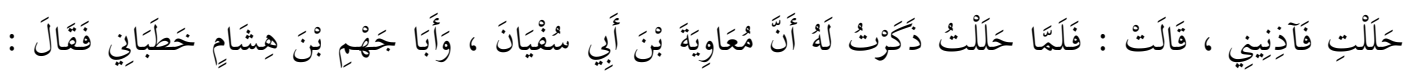

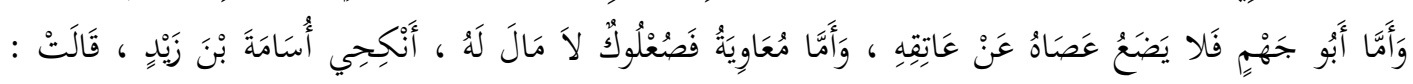

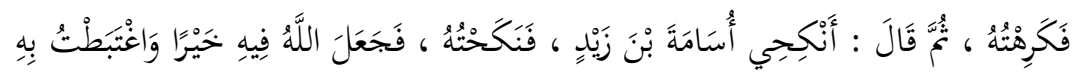

" Dari Abu Salamah bin Abdurrahman dari Fathimah binti Qais bahwa Abu Amru bin Hafsh telah menceraikannya dengan talak tiga, sedangkan dia jauh darinya, lantas dia mengutus seorang wakil kepadanya (Fathimah) dengan membawa gandum, (Fathimah) pun menolaknya. Maka (Wakil 'Amru) berkata; Demi Allah, kami tidak punya kewajiban apa-apa lagi terhadapmu. Karena itu, Fathimah menemui Rasulullah shallallahu 'alaihi wasallam untuk menanyakan hal itu kepada beliau, beliau bersabda: "Memang, dia tidak wajib lagi memberikan nafkah." Sesudah itu, beliau menyuruhnya untuk menghabiskan masa iddahnya di rumah Ummu Syarik. Tetapi kemudian beliau bersabda: "Dia adalah wanita yang sering dikunjungi oleh para sahabatku, oleh karena itu, tunggulah masa iddahmu di rumah Ibnu Ummi Maktum, sebab dia adalah laki-laki yang buta, kamu bebas menaruh pakaianmu di sana, jika kamu telah halal (selesai masa iddah), beritahukanlah kepadaku." Dia (Fathimah) berkata; Setelah masa iddahku selesai, kuberitahukan hal itu kepada beliau bahwa Mu'awiyah bin Abi Sufyan dan Abu Al Jahm telah melamarku, lantas Rasulullah shallallahu 'alaihi wasallam bersabda: "Abu Jahm adalah orang yang tidak pernah meninggalkan tongkatnya dari lehernya (suka memukul -

${ }^{25}$ Wahbah Zuhaily, al-Fiqh al-Islami Wa Adillatuhu, (Damaskus : Darul Fikr, 1985 ), Juz 7, 230. 
pent), sedangkan Mu'awiyah adalah orang yang miskin, tidak memiliki harta, karena itu nikahlah dengan Usamah bin Zaid." Namun saya tidak menyukainya, beliau tetap bersabda: "Nikahlah dengan Usamah." Lalu saya menikah dengan Usamah, Allah telah memberikan limpahan kebaikan padanya hingga bahagia." 26

Sedangkan Jumhur Fuqaha', diantaranya adalah Ulama Empat Madzhab berpendapat bahwa kafaah sangat penting dalam perkawinan meskipun kafaah bukan merupakan syarat sah suatu perkawinan dan hanya merupakan syarat lazim suatu perkawinan. Mereka mengemukakan dalil berdasarkan Hadits Rasulullah dan akal (rasio). ${ }^{27}$

Diantara Hadits-Hadits Nabi SAW. yang menjelaskan tentang kafa'ah adalah :

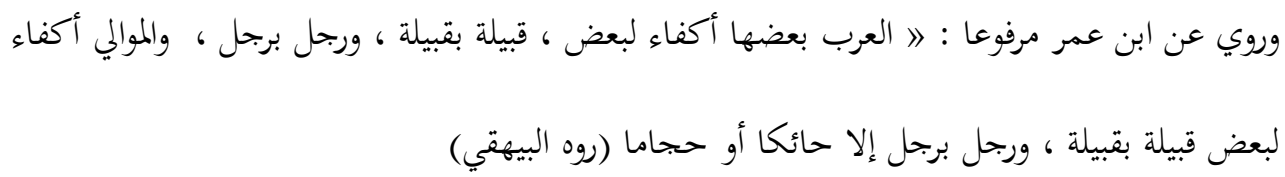

"Dari Ibnu Umar bahwa sesungguhnya Rasulullah saw. Bersabda : "Orang arab satu dengan lainnya sekufu'. Satu kabilah sekufu' dengan kabilah yang sama, satu kelompok sekufu' dengan kampung yang sama, antara sesama laki-laki diantara sekufu' kecuali tukang jahit atau bekam." (HR. Al-Baihaqi). ${ }^{28}$

Adapun secara rasio mereka berpendapat bahwa kehidupan rumah tangga sepasang suami isteri akan bahagia dan harmonis jika ada kekufu'an antara keduanya kafaah diukur dari pihak perempuan bukan dari pihak laki-laki. karena biasanya pihak perempuan yang mempunyai derajat tinggi akan merasa terhina bila menikah dengan laki-laki yang berderajat rendah. Berbeda dengan laki-laki, ia tidak akan merasa hina bila ia menikah dengan perempuan yang berderajat rendah darinya. $^{29}$

Apabila seorang perempuan yang berderajat tinggi menikah dengan lakilaki yang lebih rendah derajatnya, berdasarkan adat kebiasaan, si isteri akan merasa malu dan hina dan si suami seharusnya menjadi kepala rumah tangga yang dihormati akan menjadi rendah dan merasa kurang pantas berdiri sejajar dengan si

\footnotetext{
${ }^{26}$ Imam Baihaqi, 2005, Sunan Shugro Lil Baihaqi, Beirut, Darul Kutub Ilmiah, Juz 2, hal 364.

${ }^{27}$ Wahbah Zuhaily, al-Fiqh al-Islami Wa Adillatuhu, (Damaskus : Darul Fikr, 1985 ), Juz 7, hal.
}

232.

${ }^{28}$ Abu Bakar al-Baihaqi, 2003, Sunan Kubro, Beirut : Darul Kutub Ilmiyah, Juz 7, hal. 212.

${ }^{29}$ Sayyid Sabiq, Fiqh As-Sunnah, (Mesir : Darul Hadist, 2004), 572. 
isteri, dan pada akhirnya, keharmonisan dan kebahagiaan rumah tangga yang merupakan tujuan utama perkawinan tidak akan tercapai. ${ }^{30}$

Namun dikalangan ulama Hanafiyah terdapat perbedaan pendapat tentang kedudukan kafaah dalam perkawinan. Mereka mengatakan bahwa kafaah merupakan syarat lazim (kelangsungan) sebuah perkawinan. Tetapi menurut ulama Hanafiyah muta'akhirin, kafaah menjadi syarat sah perkawinan dalam kondisikondisi tertentu, yaitu :

a. Apabila seorang perempuan baligh berakal menikahkan dirinya sendiri dengan seorang laki-laki yang tidak sekufu' atau dalam perkawinan itu terdapat unsur penipuan, maka dalam hal ini wali dari kelompok ashabah seperti ayah dan kakek berhak untuk tidak menyetujui perkawinan sebelum terjadinya akad.

b. Apabila seorang wanita yang tidak cakap bertindak hukum, seperti anak kecil atau orang gila, dinikahkan oleh walinya selain ayah atau kakek dengan orang yang tidak sekufu', maka perkawinan itu fasiq karena tugas wali terkait dengan kemaslahatan anak perempuan tersebut, menikahkan anak perempuan itu dengan orang yang tidak sekufu' dipandang tidak mengundang kemaslahatan sama sekali.

c. Apabila seorang ayah dikenal sebagai orang yang pilihannya selalu buruk, menikahkan anak perempuan yang belum atau tidak cakap bertindak hukum dengan seorang yang tidak sekufu' maka pernikahannya menjadi batal. ${ }^{31}$

\section{Standarisasi Kafaah Menurut Ulama Madzhab Empat}

a. Agama

Dalam hukum perkawinan Islam, para ulama mempunyai prespektif tersendiri tentang konsep agama, seperti terjaganya seorang dari perbuatan keji serta tetap konsisten dalam menegakkan hukum-hukum agama. Agama dalam hal ini dimaksudkan sebagai ketidakfasikan. Dalam hal ini ulama sepakat bahwa seorang laki-laki yang fasiq tidak sekufu' dengan perempuan yang shalihah. Rasulullah SAW. bersabda :

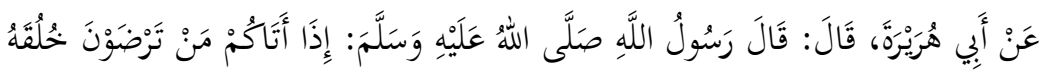

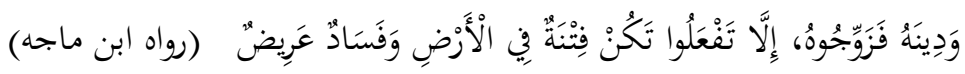

\footnotetext{
${ }^{30}$ Wahbah Zuhaily, al-Fiqh al-Islami Wa Adillatuhu, (Damaskus : Darul Fikr, 1985 ), Juz 7, 239..

${ }^{31}$ Ibid, 235.
} 
"Dari Abi Hurairoh ia berkata : Rasulullah SAW. Bersabda : "Jika datang kepadamu laki-laki yang agama dan akhlaknya kamu sukai, maka kawinkanlah, jika kamu tidak berbuat demikian aka terjadi fitnah dan kerusakan di atas bumi. "( HR. Ibnu Majah) ${ }^{32}$

Hadits di atas ditujukan kepada para wali agar mengawinkan perempuan-perempuan yang diwakilinya dengan laki-laki yang beragama dan berakhlak. Bila mereka tidak mau mengawinkan dengan laki-laki yang berakhlak luhur, tetapi memilih laki-laki yang berkedudukan tinggi atau keturunan mulia atau yang berharta, maka dapat menimbulkan fitnah dan kerusakan bagi perempuan tersebut dan walinya.

Dalam Alquran surat As-Sajadah ayat 18, Allah swt berfirman :

$$
\text { أَفََنْ كَانَ مُؤْمِنًا كَمَنْ كَانَ فَاسِقًا لَا يَسْتَوُونَ (السجدة : 18) }
$$

"Maka apakah orang yang beriman seperti orang yang fasik (kafir)? Mereka tidak sama.". ${ }^{33}$ (QS; As-Sajadah : 18)

Ayat di atas menjelaskan bahwa seorang muslim yang shaleh sama (sekufu') dengan muslimah shalihah. Dan seorang muslim yang shaleh tidak sama (sekufu') dengan seorang yang fasiq.

Selanjutnya dalam Alquran surat al-Hujurat ayat 13 :

$$
\text { إِنَّ أَكْرَمَكُمْ عِنْدَ اللَّهِ أَتَقَاكُمْ (الحجرات : 13) }
$$

"Sesungguhnya orang yang paling mulia di antara kamu di sisi Allah ialah orang yang paling bertakwa di antara kamu" (QS. al-Hujurat: 13) ${ }^{34}$

Manusia seluruhnya adalah anak cucu Adam, sedang Adam itu diciptakan dari tanah. Diriwayatkan oleh Ibnu Sa'ad dari Abu Hurairah, dan di dalamnya tidak ada kalimat "kulluhum" (seluruhnya).

Diriwayatkan oleh Ibnu la' Ali dengan susunan matan yang hampir sama dengan susunan matan hadis dari Sahal bin Sa'ad. Al-Bukhari mengisyaratkan kepada dukungannya terhadap pendapat itu, dimana beliau

\footnotetext{
${ }^{32}$ Ibnu Majah, Sunan Ibnu Majah, (Kairo : Darul Ihya`, 2004), Juz 1, hal. 632.

${ }^{33}$ Departemen Agama RI, Al-Qur'an dan Terjemahnya, (Bandung : Jabal Raudlotul Jannnah, 2010), 416.

${ }^{34}$ Departemen Agama RI, Al-Qur'an dan Terjemahnya, (Bandung : Jabal Raudlotul Jannnah, 2010), 517.
} 
berkata: Bab sekufu' dalam agama. Dan firman Allah dalam surat Al-Furqan ayat 54 yang berbunyi :

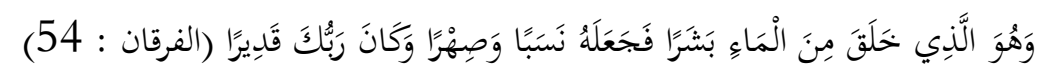

"Dan Dia (pula) yang menciptakan manusia dari air, lalu Dia jadikan manusia itu (punya) keturunan dan mushaharah dan adalah Tuhanmu Maha Kuasa." (Q.S. Al-Furqan: 54). ${ }^{35}$

Dari ayat Alquran di atas dapat diambil kesimpulan bahwa kedudukan manusia itu sama di hadapan Allah, yang satu dengan yang lain tidak ada bedanya, sama-sama terbuat dari air mani. Kemudian Rasulullah susul ajaran persamaan manusia itu dengan perintahnya kepada Abu Huzaifah untuk menikahkan Salim dengan anak perempuan saudaranya yang bernama Hindun binti Al-Walid bin Utbah bin Rabi'ah (bangsawan). Padahal Saim itu adalah hamba sahaya seorang perempuan Anshar.

\section{b. Nasab}

Jumhur ulama (Hanafiyah, Syafi'iyah, dan Hanabilah) selain Malikiyah berpendapat bahwa nasab merupakan salah satu hal yang paling penting dan masuk dalam kafaah, karena ada beberapa alasan mendasar yang mengilhami mereka, seperti banyaknya orang Islam, khususnya orang muslim arab yang sangat fanatik dalam menjaga keturunan dan golongan mereka. Alasan mereka memasukkan nasab dalam kafaah berdasarkan Hadits Nabi SAW :

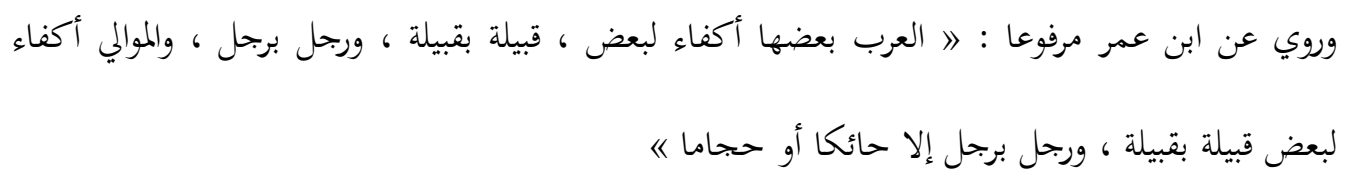

"Dari Ibnu Umar bahwa sesungguhnya Rasulullah SAW. Bersabda : Orang arab satu dengan lainnya sekufu'. Satu kabilah sekufu' dengan kabilah yang sama, satu kelompok sekufu' dengan kampung yag sama, antara sesama lakilaki diantara sekufu' kecuali tukang jahit atau bekam." (HR. Baihaqi). ${ }^{36}$

Maksud dari Hadits di atas adalah bahwa orang arab sepadan dengan orang arab, orang arab tidak sekufu' dengan selain orang arab, kabilah yang satu sekufu' dengan kabilahnya, bekas budak sekufu' dengan bekas budak.

\footnotetext{
${ }^{35}$ Departemen Agama RI, Al-Qur'an dan Terjemahnya, (Bandung : Jabal Raudlotul Jannnah, 2010), 364.

${ }^{36}$ Abu Bakar al-Baihaqi, Sunan Kubro, Beirut : Darul Kutub Ilmiyah, 2003), Juz 7, 212.
} 
Jadi seseorang yang dianggap sekufu' jika ia dari golongan yang sama. Menurut ulama Hanafiyah, nasab (keturunan) dalam kafaah hanya dikhususkan pada orang-orang arab. Dengan demikian suami dengan isteri harus sama kabilahnya. Jika seorang suami dari bangsa Quraisy, maka nasabnya sebanding dengan perempuan yang berasal dari bangsa Quraisy.

Dari sini diketahui bahwa laki-laki selain bangsa arab tidak sebanding dengan perempuan Quraisy dan perempuan arab. Orang arab yang bukan dari kabilah Quraisy tidak sebanding dengan perempuan Quraisy. Adapun menurut ulama Syafi'iyah, orang arab sebanding dengan Quraisy lainnya kecuali dari Bani Hasyim dan Muthalib karena tidak ada orang Quraisy yang sebanding dengan mereka (Bani Hasyim dan Bani Muthalib). Dan yang menjadi pertimbangan dalam hal nasab adalah bapak.

Sedangkan ulama Hanafiyah berpendapat bahwa golongan Quraisy sebanding dengan Bani Hasyim. Golongan Malikiyah berpendapat seperti yang dijelaskan dalam kitab Fiqh Islam Wa Adillatuhu, bahwa dalam Islam tidak ada perbedaan antara satu golongan dengan dengan golongan yang lain, bagi orang arab maupun non-arab yang terpenting bagi golongan Malikiyah adalah keimanan dan ketakwaan seseorang terhadap Allah SWT.

\section{c. Merdeka}

Yang dimaksud merdeka di sini adalah bukan budak (hamba sahaya). Jumhur ulama selain Malikiyah memasukkan merdeka dalam kafaah berdasarkan Alquran surat an-Nahl ayat 75 :

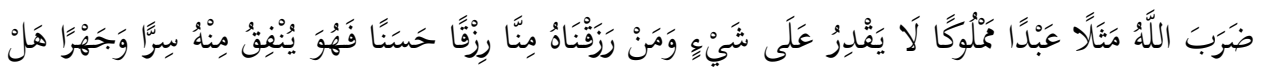

$$
\begin{aligned}
& \text { يَسْنَوُونَ (النحل : 75) }
\end{aligned}
$$

"Allah membuat perumpamaan dengan seorang hamba sahaya yang dimiliki yang tidak dapat bertindak terhadap sesuatupun dan seorang yang Kami beri rezeki yang baik dari Kami, lalu dia menafkahkan sebagian dari rezki itu secara sembunyi dan secara terang-terangan, adakah mereka itu sama?". (QS. An-Nahl: 75). ${ }^{37}$ hal. 275 .

\footnotetext{
${ }^{37}$ Departemen Agama RI, 2010, Al-Qur'an dan Terjemahnya, Bandung : Jabal Raudlotul Jannnah,
} 
Dalam ayat di atas dijelaskan bahwa seorang budak dimiliki olehtuannya dan dia tidak dapat melakukan sesuatu pun termasuk menafkahkan hartanya sesuai dengan keinginannya kecuali atas perintah tuannya. Akan tetapi orang merdeka bebas melakukan sesuatu sesuai dengan keinginannya tanpa menunggu perintah dari siapapun. Jadi, budak laki-laki tidak kufu' dengan perempuan merdeka. Budak laki-laki yang sudah merdeka tidak kufu' dengan perempuan yang merdeka sejak asalnya. Laki-laki yang salah seorang neneknya pernah menjadi budak. Hal ini karena perempuan merdeka bila ia dikawini oleh laki-laki yang salah seorang neneknya pernah menjadi budak. ${ }^{38}$

\section{d. Harta}

Yang dimaksud dengan harta adalah kemampuan seseorang (calon suami) untuk memberikan mahar dan nafkah kepada isterinya. Menurut ulama Hanafiyah dan Hanabilah, harta merupakan hal yang penting dalam kehidupan rumah tangga sehingga harta dianggap penting untuk dimasukkan dalam kriteria kafaah.

Ulama Hanafiyah dan Hanabilah mengatakan bahwa yang dianggap sekufu' adalah apabila seorang laki-laki sanggup membayar mahar dan nafkah kepada isterinya. Apabila tidak sanggup membayar mahar dan nafkah atau salah satudiantara keduanya, maka dianggap tidak sekufu'. Menurut Abu Yusuf (salah satu sahabat Abu Hanifah) yang dianggap sekufu' dalam harta adalah kesanggupan memberi nafkah bukan membayar mahar. Sebab ukuran yang mudah dilakukan dan kemampuan seseorang untuk memberi nafkah itu tidak dapat dilihat dari keadaan bapaknya. ${ }^{39}$

Adapun ulama Malikiyah dan sebagian ulama Syafi'iyah menentang penggolongan harta dalam kriteria kafaah. Menurut mereka harta memangdianggap sebagai suatu hal yang tidak penting dalam kehidupan rumah tangga sekalipun itu merupakan kebutuhan. Memasukkan harta dalam ukuran

\footnotetext{
${ }^{38}$ Sayyid Sabiq, Fiqh As-Sunnah, Mesir : Darul Hadist, 2004), 575.

${ }^{39}$ Umar Faruq Thohir (2018) "Korelasi Pendapatan Ekonomi dan Kedewasaan Pasangan Terhadap Keharmonisan Rumah Tangga Pelaku Pernikahan di Bawah Umur di Desa Wedusan, Tiris, Probolinggo.”, Asy-Syari'ah: Jurnal Hukum Islam , 4 (1), 77.
} 
kafaah sama halnya mengajari atau mendidik umat Islam untuk tidak berakhlak terpuji seperti yang diajarkan Nabi SAW. ${ }^{40}$

\section{e. Pekerjaan}

Yang dimaksud dengan pekerjaan adalah adanya mata pencaharian yang dimiliki seseorang untuk dapat menjamin nafkah keluarga. ${ }^{41}$ Jumhur ulama selain Malikiyah sepakat memasukkan pekerjaan dalam perangkat kafaah berdasarkan Hadits Nabi SAW :

$$
\text { وروي عن ابن عمر مرفوعا : العرب بعضها أكفاء لبعض ، قبيلة بقبيلة ، ورجل برجل ، }
$$

"Dari Ibnu Umar bahwa sesungguhnya Rasulullah SAW. bersabda : "Orang arab satu dengan lainnya sekufu', satu kabilah sekufu' dengan kabilah yang sama, satu kelompok sekufu' dengan kampung yang sama, antara sesama sesama laki-laki diantara sekufu' kecuali tukang jahit atau bekam”." (HR. Baihaqi). ${ }^{42}$

Dalam Hadits di atas dijelaskan bahwa seseorang yang mempunyai pekerjaan terhormat sekufu' dengan orang yang mempunyai pekerjaan terhormat juga. Begitu juga sebaliknya, seseorang yang mempunyai pekerjaan terhormat tidak sekufu' dengan seseorang yang pekerjaannya tukang bekam.

Menurut Jumhur Ulama, pekerjaan seorang laki-laki minimal mendekati pekerjaan keluarga keluarga wanita. Sedangkan menurut golongan Hanafiyah, penghasilan laki-laki harus sebanding dengan penghasilan pihak keluarga perempuan sesuai dengan adat yang berlaku. Apabila menjahit menurut adat lebih tinggi derajatnya dibanding menenun, maka penjahit itu tidak sebanding dengan anak penenun, maka penjahit itu tidak sebanding dengan anak penenun.

Menanggapi permasalahan ini golongan Malikiyah berpendapat tidak ada perbedaan mengenai pekerjaan, semua itu dapat berubah sesuai dengan takdir Allah, sehingga pekerjaan bagi ulama Malikiyah tidak dimasukkan dalam kriteria kafaah. ${ }^{43}$

\footnotetext{
${ }^{40}$ Wahbah Zuhaily, al-Fiqh al-Islami Wa Adillatuhu, (Damaskus : Darul Fikr, 1985 ), Juz 7, 246.

${ }^{41}$ Ibid, 246.

${ }^{42}$ Abu Bakar al-Baihaqi, Sunan Kubro, Beirut : Darul Kutub Ilmiyah, 2003), Juz 7, 212.

${ }^{43}$ Wahbah Zuhaily, al-Fiqh al-Islami Wa Adillatuhu , (Damaskus : Darul Fikr, 1985 ), Juz 7, 247.
} 


\section{f. Seimbang dari Segi Fisik atau Tidak Cacat}

Murid-murid Syafi'i dari riwayatnya Ibnu Nasir dari Malik bahkan salah satu syarat kufu' ini adalah selamat dari cacat. Bagi laki-laki yang mempunyai cacat jasmani yang menyolok itu tidak sekufu' dengan perempuan sehat dan normal. Jika cacatnya pandangan lahiriyah, seperti buta, laki-laki yang seperti ini tidak sekufu' dengan perempuan sehat, tetapi kurang disukai menurut pandangan lahiriah, seperti buta, tangan buntung atau perawakannya jelek. Dalam hal ini ada dua pendapat. Rauyani berpendapat bahwa lelaki seperti ini tidak kufu' dengan perempuan sehat, tetapi golongan Hanafi dan Hanbali tidak menerima pendapat ini. Dalam kitab al-Mughni terhindar dari cacat tidak termasuk dalam syarat kufu', tidak seorangpun menyalahi pendapat ini, yaitu kawinnya orang yang cacat itu tidak batal.

Hanya pihak perempuan mempunyai hak untuk menerima atau menolak, bukan walinya karena resikonya tentu dirasakan oleh si perempuan.Walaupun demikian, wali perempuan boleh mencegahnya untuk kawindengan laki-laki berpenyakit kusta, gila, tangannya buntung atau kehilangan tangannya. Imamiyah berpendapat bahwa, sopak dan kusta adalah dua penyakit yang menyebabkan seorang laki-laki boleh melakukan fasakh, tetapi tidak boleh bagi kaum wanita, dengan syarat bahwa hal itu terjadi sebelum akad nikah dan laki-laki tersebut tidak mengetahuinya. Sedangkan bagi istri, ia tidak mempunyai hak untuk melakukan fasakh, manakala salah satu dari penyakit tersebut terjadi pada laki-laki (suaminya).

Imam Syafi'i, Maliki, dan Hambali berpendapat bahwa kedua penyakit tersebut merupakan cacat bagi kedua belah pihak, laki-laki dan perempuan. Kedua belah pihak boleh melakukan fasakh manakala menemukan penyakit tersebut ada pada pasangannya. Orang yang menderita penyakit tersebut, bagi Imam Syafi'i dan Imam Hambali, hukumnya sama dengan orang-orang gila.

Sementara itu, Imam Malik mengatakan bahwa kaum wanita boleh memfasakh manakala penyakit tersebut ditemukan sebelum dan sesudah akad nikah. Sedangkan laki-laki boleh melakukan fasakh manakala penyakit kusta dalam diri wanita tersebut ditemukan sebelum atau ketika akad. Sedangkan sopak, manakala ditemukan sebelum akad, maka kedua belah pihak memiliki 
hak fasakh. Tetapi kalau sopak tersebut terjadi sesudah akad, maka hak tersebut hanya bagi wanita dan tidak bagi laki-laki. Adapun sopak yang ringan yang ditemukan sesudah akad, tidak berpengaruh terhadap kelangsungan akad. Terhadap orang yang menderita sopak atau kusta, hakim harus memberikan masa tenggang setahun penuh bila ada kemungkinan sembuh dalam jangka waktu ini.

Ibnu Qudamah dalam kitabnya al-Mughi berpendapat bahwa syarat tidak cacat itu bukan ukuran kafaah. Tidak ada perbedaan pendapat bahwa perkawinan itu tidak batal dengan tidak adanya kafaah, akan tetapi pihak perempuan serta wakilnya berhak meminta khiyar (memilih) untuk meneruskan atau membatalkan perkawinan tersebut. Wali boleh mencegah perkawinan apabila anak gadisnya kawin dengan laki-laki yang berpenyakit kusta, gila, selain cacat-cacat tersebut tidak dianggap sebagai ukuran kafa'ah. ${ }^{44}$

\section{KESIMPULAN}

Ulama Madzhab Empat memiliki pendapat berbeda tentang kedudukan dan standarisasi kafaah dalam pernikahan. Dalam masalah standarisasi kafaah, menurut ulama` Hanafiyah adalah nasab, islam, profesi dalam kehidupan, kemerdekaan dirinya, tingkat kualitas keberagamaan dan kekayaan. Menurut Ulama Malikiyah yang menjadi standarisasi kafaah hanyalah tingkat kualitas keberagamaannya dan bebas dari cacat fisik. Menurut ulama' Syafi’iyah yang menjadi standarisasi kafaah adalah nasab, kualitas keberagamaan., kemerdekaan diri, Usaha atau profesi. Menurut ulama Hanabilah yang menjadi standarisasi kafaah adalah kualitas keberagamaan, usaha atau profesi, kekayaan, dan kemerdekaan diri. Ada juga sebagian ulama yang berpendapat bahwa faktor agamalah yang paling penting untuk dijadikan standarisasi kafaah berdasarkan penekanan hadits Nabi yang berbunyi فاظفر بذات الدين. Sedangkan dalam masalah kedudukan kafaah, ulama' Madzhab Empat dalam pendapat rajihnya kelompok Hanabilah, pendapat mu`tamadnya kelompok Malikiyah dan pendapat adzharnya kelompok Syafi`iyah sepakat bahwa kafaah adalah syarat luzum dalam pernikahan.

\footnotetext{
${ }^{44}$ Sayyid Sabiq, Fiqh As-Sunnah, (Mesir : Darul Hadist, 2004), 576.
} 


\section{DAFTAR PUSTAKA}

Abu Abdillah al-Hakim an-Naisaburi, Muhammad Bin Abdillah, Al-Mustadrok `Ala asShohihaini, (Beirut : Darul Kutub Ilmiyah, 1990).

Abu Bakar, al-Baihaqi, Sunan Kubro, Beirut : Darul Kutub Ilmiyah, 2003).

Adnan Quthny, Abu Yazid, (2016) "Reformasi Hukum Keluarga Islam Turki (Status

Poligami dalam Perspektif Teori Linguistik-Semantik Muhammad Shahrur)", Asy-

Syari'ah: Jurnal Hukum Islam , 2 (1).

Ali al-Qunuwi, Qosim Bin Abdullah Bin Amir ', Anisul Fuqoha`Fi Ta`rifil alfadz alMutadawilah Bainal Fuqoha， (Beirut: Darul Fikr, 1999) .

Departemen Agama RI, Al-Qur'an dan Terjemahnya, (Bandung : Jabal Raudlotul Jannnah, 2010).

Hosen, Ibrahim, Fiqh Perbandingan Dalam Masalah Pernikahan , (Jakarta: Pustaka Firdaus , 2003).

Ibnu Majah, Sunan Ibnu Majah, (Kairo : Darul Ihya', 2004).

Ibnu Rusyd, Bidayatul Mujtahid, (Beirut : Darul Ibni `Asshoshoh, 2005).

Imam al-Baihaqi, Sunan Sughro Lil Baihaqi, Damaskus : Darut Tauqi an-Najah, 2002).

Imam Suyuthi, Jami`ul Kabir, (Beirut : Darul Kutub Ilmiyah, 1990).

Imam Syafi'i. 2020. "Konsep Kafaah Dan Keluarga Sakinah (Studi Analisis Tentang

Korelasi Hak Kafa'ah Terhadap Pembentukan Keluarga Sakinah)". Asy-Syari'ah:

Jurnal Hukum Islam 6 (1).

Jalaluddin as-Suyuthi, Jami`u al-Ahadist, , (Beirut : Darul Ibni`Asshoshoh, 2005).

Muzakki, Ahmad. 2017. "Kafaah Dalam Pernikahan Endogami Pada Komunitas Arab Di

Kraksaan Probolinggo”. Istidlal: Jurnal Ekonomi Dan Hukum Islam 1 (1).

Noeng Muhajir, Metodologi Penelitian Filsafat, (Yogyakarta: Rike Sarasin, 1996).

Sayyid Sabiq, Fiqh As-Sunnah, (Mesir : Darul Hadist, 2004).

Syaikh Imad Zaki al-Barudi, Tafsir Wanita, Jakarta: Pustaka al-Kautsar, 2008).

Thohir, Umar Faruq (2018) "Korelasi Pendapatan Ekonomi dan Kedewasaan Pasangan

Terhadap Keharmonisan Rumah Tangga Pelaku Pernikahan di Bawah Umur di

Desa Wedusan, Tiris, Probolinggo.”, Asy-Syari'ah: Jurnal Hukum Islam , 4 (1).

Wahbah Zuhaily, al-Fiqh al-Islami Wa Adillatuhu, (Damaskus : Darul Fikr, 1985 ) 